\title{
MMADHC wt Allele
}

National Cancer Institute

\section{Source}

National Cancer Institute. MMADHC wt Allele. NCI Thesaurus. Code C74466.

Human MMADHC wild-type allele is located in the vicinity of 2 q23.2 and is approximately $18 \mathrm{~kb}$ in length. This allele, which encodes Methylmalonic aciduria and homocystinuria type D protein, mitochondrial, plays a role in the mediation of vitamin B12 metabolism. Mutation of the gene is associated with some cases of homocystinuria, and methylmalonic aciduria. 